\title{
12. GEOCHEMISTRY OF AMINO ACIDS IN INTERSTITIAL WATER, LEG 116 ${ }^{1}$
}

\author{
Toshio Ishizuka, ${ }^{2}$ Venugopalan Ittekkot, ${ }^{3}$ and Hodaka Kawahata ${ }^{4}$
}

\begin{abstract}
We report the results of dissolved free amino acid and hydrolyzable amino acid analysis from interstitial water samples collected from Ocean Drilling Project Leg 116. The total hydrolyzable amino acid (THAA) values range between 3.7 and $38.6 \mu \mathrm{M}$. They average $16.1 \mu \mathrm{M}$ at Site 717 ; between 3.18 and $29.72 \mu \mathrm{M}$, averaging $13.66 \mu \mathrm{M}$ at Site 718; and between 2.57 and $46.44 \mu \mathrm{M}$, averaging $14.60 \mu \mathrm{M}$ at Site 719. The dissolved free amino acid (DFAA) values show between 2.24 and $37.7 \mu \mathrm{M}$, averaging $9.45 \mu \mathrm{M}$ at Site 717 ; between 0.43 and $21.64 \mu \mathrm{M}$, averaging 10.1 $\mu \mathrm{M}$ at Site 718; and between 0.91 and $12.92 \mu \mathrm{M}$, averaging $6.6 \mu \mathrm{M}$. DFAA in the Bay of Bengal, at Sites 717, 718, and 719 constitute, in most cases, less than $50 \%$ of the THAA in the pore water at the sediment surface, and this ratio increases downsection. Concentrations approach $100 \%$ in the deepest interstitial water samples. Sulfate reduction and methane fermentation are the only bacterial processes acting in the deeper sediment samples of the Bay of Bengal, Leg 116. Bacteria first act to easily decompose proteins and carbohydrates within the sedimentary organic matter. However, it may be more difficult for bacteria to further decompose organic matter after the decomposition of protein and carbohydrate, and to make a large colony change free amino acid to its inorganic constituents.
\end{abstract}

\section{INTRODUCTION}

The concentration and composition of amino acids in marine sediment have been investigated mostly in the coastal environments where active biogeochemical cycling of organic matter is taking place (Degens and Mopper, 1976, Rosenfeld, 1979, Henriches and Farrington, 1979, 1987). Some data have also been reported for the hydrolysates of hemipelagic and deep-sea sediments (Mooris, 1975, Whelan, 1977, Henriches and Farrington, 1979, Ishizuka et al., 1988). However, for deep-sea environment, studies of amino acids in pore water have been scarce. To our knowledge, the results of Michaelis et al. (1982), Ishizuka et al. (1988), Kawahata and Ishizuka (1989), and Kawahata et al. (in press) are the only recently available data in the literature relevant to deep-water sediments recovered by drilling and piston coring.

The purpose of this study, therefore, is to determine the detailed vertical distribution of amino acids in interstitial water of deep-sea sediment and discuss the possible origin of organic material and its relationships with interstitial waters.

\section{SAMPLING AND STORAGE}

The interstitial waters in sediment cores from Sites 717, 718 , and 719 were collected on JOIDES Resolution by hydraulic squeezing. All interstitial water samples were filtered through $0.22 \mu \mathrm{m}$ Millipore cellulose acetate filters in the shipboard laboratory. For amino acid analysis, a $5 \times 10^{-3} \mathrm{dm}^{3}$ aliquot of the water sample was placed into a precombusted glass ampule. The ampule was sealed after flushing with nitrogen gas and returned to the land-based laboratory.

\footnotetext{
${ }^{1}$ Cochran, J. R., Stow, D.A.V., et al., 1990. Proc. ODP, Sci. Results, 116 : College Station, TX (Ocean Drilling Program).

2 Ocean Research Institute, University of Tokyo, Nakano, 164 Tokyo, Japan.

${ }^{3}$ University of Hamburg, Geological Paleontological Institute, Bundesstrasse 55, 200 Hamburg, Federal Republic of Germany.

${ }^{4}$ Geological Survey of Japan, Tsukuba, 305 Japan.
}

\section{METHOD}

\section{Analysis of Amino Acids}

Dissolved free amino acids (DFAA) in interstitial water were analyzed after the addition of $7 \times 10^{-6} \mathrm{dm}^{3}$ of ultrapure (amino acid-free) $2 \mathrm{M} \mathrm{HCl}$ with $0.7 \times 10^{-3} \mathrm{dm}^{3}$ of an interstitial water sample. Each amino acid concentration was determined by direct injection into an automated high-performance liquid chromatograph analyzer (Hitachi Model 835) module. The reagent blank was suitably corrected.

For total hydrolyzable amino acids (THAA), $1 \times 10^{-3} \mathrm{dm}^{3}$ of the interstitial water, together with $1 \times 10^{-3} \mathrm{dm}^{3}$ of the ultrapure concentrated $\mathrm{HCl}$, was placed into a precombusted glass ampule and hydrolyzed at $110^{\circ} \mathrm{C}$ for $22 \mathrm{hr}$ in an argon atmosphere. Then the solution was gently evaporated using a rotary evaporator at a temperature lower than $42^{\circ} \mathrm{C}$, and the residue was redissolved in $1 \times 10^{-3} \mathrm{dm}^{3}$ of $0.01 \mathrm{M} \mathrm{HCl}$. This aliquot was then injected into the high-performance liquid chromatography analyzer. The standard deviation for amino acid analysis based on replicate measurements of a standard solution (about $1 \mu \mathrm{M}$ for amino acids) was less than $10 \%$, and the detection limit of our method was about $0.03 \mu \mathrm{M}$. Low values in free and hydrolyzable amino acids near the detection limit may not be reliable. Nevertheless, we retain these values because they confirm that the amino acid concentration is low (Ishizuka et al., 1988).

\section{GEOLOGICAL FRAMEWORK}

Ten holes were drilled at three closely spaced sites on two adjacent rotated fault blocks near $1^{\circ} \mathrm{S}, 81^{\circ} 24^{\prime} \mathrm{E}$, located in the central Indian Ocean approximately $800 \mathrm{~km}$ south of Sri Lanka and $200 \mathrm{~km}$ northwest of the Afanasiy Nikitin seamount group (Fig. 1). Selected examples from these sites were taken to study the early diagenesis and origin of organic matter. Sedimentation at the three sites has been dominated by fan sedimentation processes since the early Miocene and consists mainly of different types of turbidites. These are mostly of silt and mud grade, but also include wood fragments and sand-sized grains. Siliceous microfossils are almost completely absent in spite of the location of the sites within the 


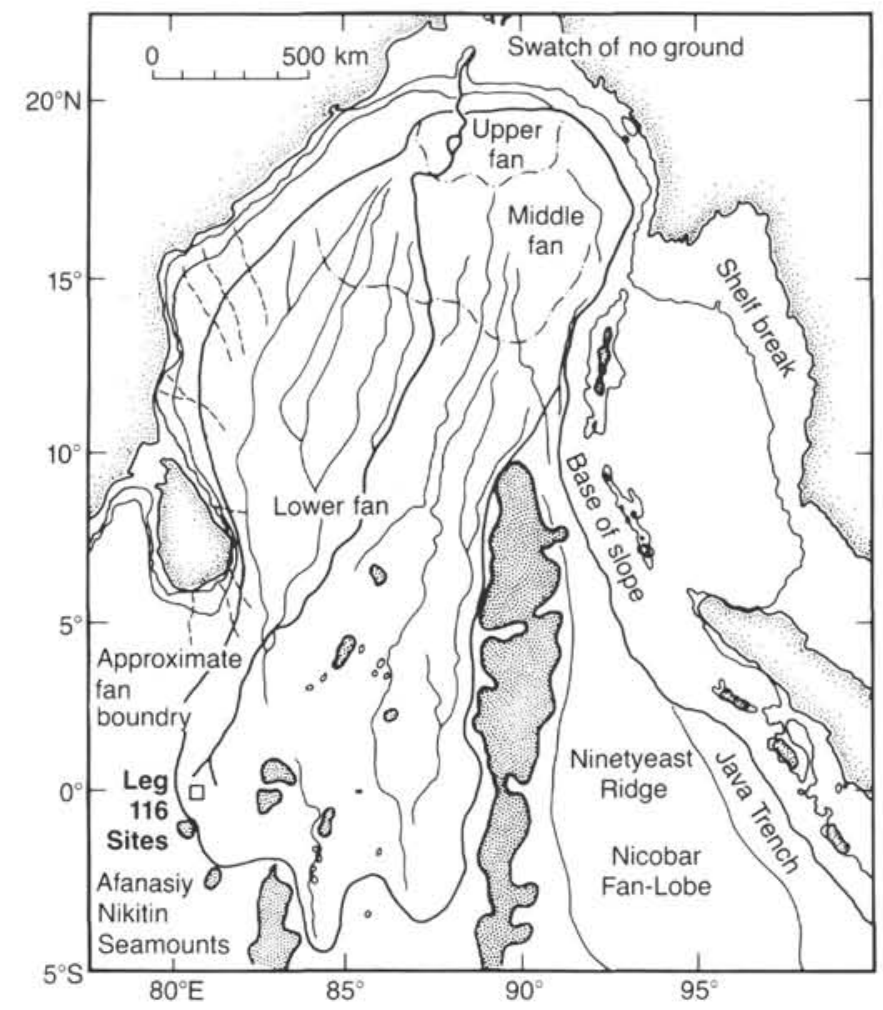

Figure 1. Location map of sampling sites, ODP Leg 116, Bay of Bengal.

supposed equatorial high-productivity zone. Calcareous microfossils are also scarce except within bioclastic turbidites. The sedimentary sequence recovered at the three sites is divided into five units. These units are very similar to each other, differing primarily in thickness and the average grain size. Unit I comprises clay and calcareous clay of Holocene to latest Pleistocene age. Unit II is dominated by micaceous silt and silty mud turbidites of late Pleistocene age. Unit III to IV is composed of mud turbidites, silty mud turbidites, and biogenic turbidites with thin interbedded and pelagic clays of Pleistocene to late Miocene age. Subunit VA comprises silt and silty mud turbidites with thin, sporadic interbeds of mud turbidites and pelagic clays of late to middle Miocene age. Subunit VB comprises similar silt and silty mud turbidites with up to 20 - $\mathrm{m}$ thick intervals of interbedded mud turbidites, biogenic turbidites and pelagic clays of middle to early $\mathrm{Mi}$ ocene age (Leg 116 Shipboard Scientific Party, 1989).

\section{RESULTS}

Total hydrolyzable amino acid (THAA) concentrations are plotted vs. depth in Figure 2. The THAA values range between 3.7 and $38.6 \mu \mathrm{M}$, averaging $16.1 \mu \mathrm{M}$ at Site 717; between 3.18 and $29.7 \mu \mathrm{M}$, averaging $13.7 \mu \mathrm{M}$ at the Site 718; and between 2.57 and $46.4 \mu \mathrm{M}$, averaging $14.6 \mu \mathrm{M}$ at Site 719 . Relatively high values are found near the surface at Sites 718 and 719 , but not at Site 717 .

The dissolved free amino acid (DFAA) values (Fig. 3) are between 2.24 and $37.7 \mu \mathrm{M}$, averaging $9.45 \mu \mathrm{M}$ at the Site 717 ; between 0.43 and $21.6 \mu \mathrm{M}$, averaging $10.1 \mu \mathrm{M}$ at Site 718 ; and between 0.91 and $12.9 \mu \mathrm{M}$, averaging $6.6 \mu \mathrm{M}$ at Site 719 . There is a discrepancy between the profiles of the organic carbon content of the sediment (Leg 116 Shipboard Scientific Party, 1989) and the THAA and DFAA in interstitial water at all three Sites 717,718 , and 719 . Neutral amino acids are the most abundant fraction of THAA and account for $46.1 \%$ at Site $717,50.3 \%$ at Site 718 , and $52.4 \%$ at Site 718 . The average concentrations are $10.0 \mu \mathrm{M}$ at Site $717,7.35 \mu \mathrm{M}$ at Site 719 , and $7.16 \mu \mathrm{M}$ at Site 718. The second-most abundant fraction is acidic amino acid. The mean concentrations are $4.02 \mu \mathrm{M}$ at Site $717,3.44 \mu \mathrm{M}$ at Site 719 , and $2.46 \mu \mathrm{M}$ at Site 718 on average, which constitute $25.3 \%$ at Site $717,23.6 \%$ at Site 719 , and $18 \%$ at Site 718 , of THAA. The basic amino acid fractions are $1.72 \mu \mathrm{M}$ at Site $717,1.80 \mu \mathrm{M}$ at Site 719 , and $2.19 \mu \mathrm{M}$ at Site 718 , which account for $10.7 \%, 12.3 \%$, and $19.1 \%$, respectively. The concentrations of neutral, acidic, and basic amino acids change continuously from Site 717 to Site 718 . This may be due to differences in the main facies present at each site and/or to differences in the rates of sedimentation. These amino acids are similar to each other at Sites 717 and 719 , because the two sites are close, about $2 \mathrm{~km}$ apart, but those amino acids at Site 718 are different from those at the other two sites because there is a fault block zone between Sites 718 and 719.

The THAA concentration becomes lower in a southerly direction between the three sites, but the average DFAA concentrations at Site 719 (in between the other two) is consistently lower than at both Sites 717 and 718 . This may be due to methanogenic bacterial activity, because $\mathrm{CH}_{4}$ concentration in the interstitial water at Site 719 is higher than that at the other sites (Leg 116 Shipboard Scientific Party, 1989). The THAA at Site 717 may be influenced by the organic matter in the sediment. In any event, there is not a good relationship between the THAA and methane concentration at Site 717, nor is there at Sites 718 and 719 except for samples from the sulfate reduction zone.

The DFAA profile data are very similar to the THAA profile data at all three sites and also similar to profiles from the flank of Costa Rica Rift (Legs 111, Kawahata and Ishizuka, 1989) and from the Weddell Sea (Leg 113, Kawahata et al., in press). These profiles are different from those of the Atlantic abyssal plain (Ishizuka et al.,1988), which had only marine organic matter and a small amount of organic carbon. The DFAA and THAA profiles show relatively large scatter beyond our analytical precision, similar to those for samples from the flank of the Costa Rica Rift and the Weddell Sea (Kawahata and Ishizuka, 1989, Kawahata et al., in press). This scatter may be explained as a real feature, caused by a complex interaction involving the organic matter type, organic matter content, bacterial activity, reaction with clay minerals, and redox of pore water.

The vertical distribution of DFAA is quite different from that of the THAA within the upper $20 \mathrm{~m}$ in the samples from the Atlantic abyssal plain (ESOPE). A difference between the DFAA and THAA profiles in the ESOPE samples (Ishizuka et al., 1988) showed that organisms ranging from bacteria to large benthic fauna play an important role in processing free amino acid. Bacteria can produce free amino acids and proteins from organic matter and transform amino acid into inorganic constituents $\left(\mathrm{NH}_{3}^{+}\right.$and $\left.\mathrm{CO}_{2}\right)$ through metabolic processes because of an active redox transition layer that could be identified from the dissolved manganese and nitrate profiles. Sulfate reduction and methane fermentation bacteria are dominant in the bacterial zone of the sediment samples from the Bay of Bengal, Leg 116. Bacteria decompose first the labile proteins and carbohydrates of deposited organic matter in near-surface bottom sediment. However, it may be difficult for bacteria to further decompose organic matter (e.g., nucleic acid) after decomposition of proteins and carbohydrates and to make a large colony change from free amino acid to inorganic constituents. Therefore, the ratios of DFAA to THAA range mostly below $50 \%$ at the surface sediment and 

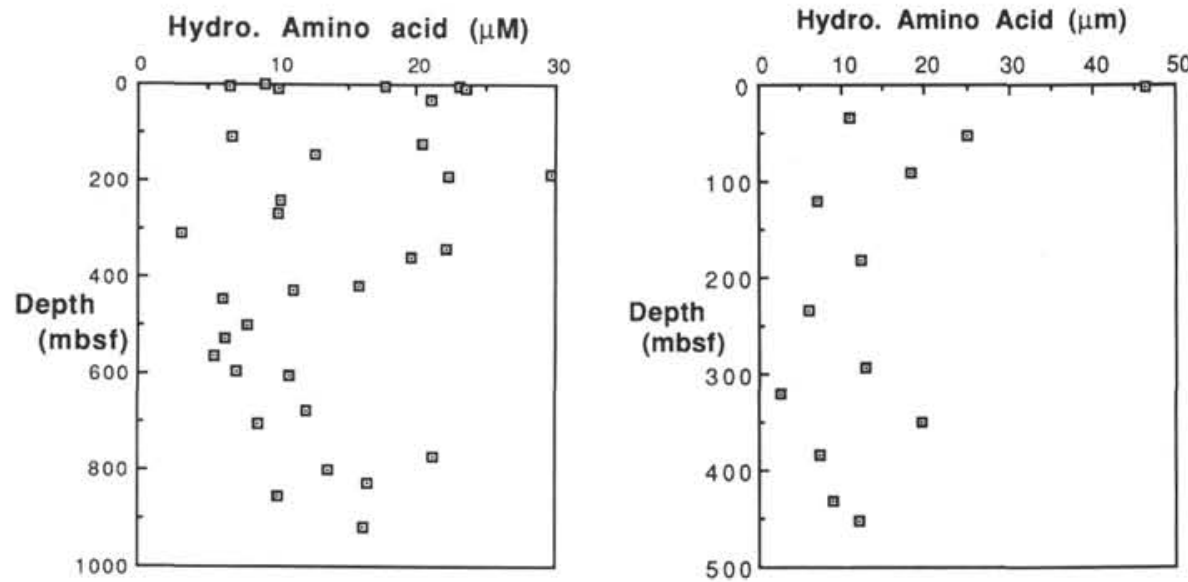

Hydro. Amino Acid $(\mu \mathrm{m})$

Figure 2. Total hydrolyzable amino acid profile of interstitial water vs. depth at Sites 718, 719, and 717 .

718

Free Amino acid $(\mu \mathrm{M})$

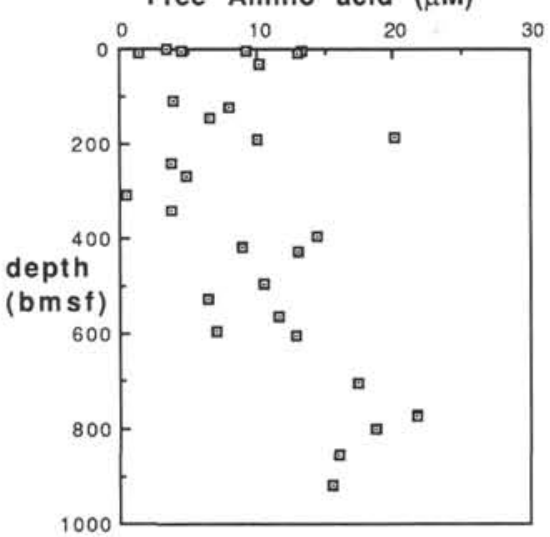

Free Amino acid $(\mu \mathbf{M})$

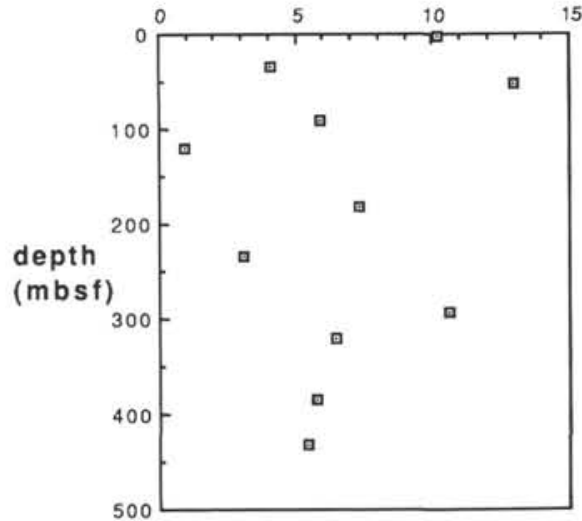

717

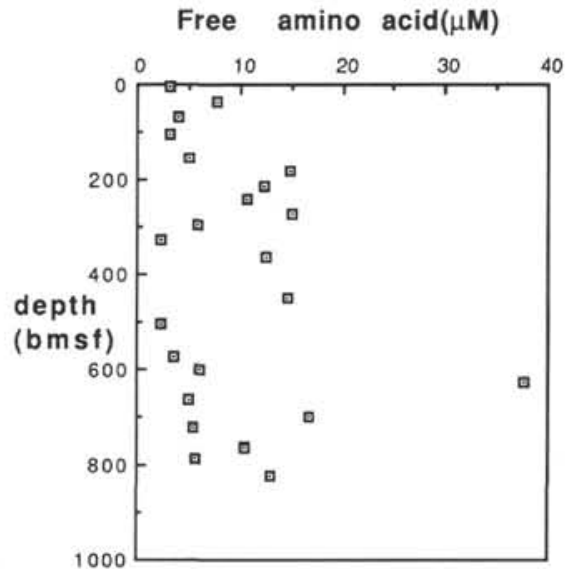

Figure 3. Dissolved free amino acid profile vs. depth at Sites 718, 719, and 717.

become steadily greater with depth to between $100 \%$ and $60 \%$, especially below $500 \mathrm{~m}$ depth (Fig. 4). This pattern differs from that found at the Flank of Costa Rica Rift, Leg 111, and in the Weddell Sea, Antarctic Ocean, Leg 113 (Kawahata and Ishizuka, 1989, and Kawahata et al., in press). This difference in the profiles is dependent on a difference of depth or on the type of bacteria and organic matter present in sediment. Two holes in Leg 116 were drilled to between 800 and $1000 \mathrm{~m}$ depth whereas the holes in both Legs 111 and 113 were drilled to only $300 \mathrm{~m}$ depth. The sediment contains woody fragments and few marine biological fossils in the Bengal Fan Sites (Leg 116 Shipboard Scientific Party, 1989), but is rich in marine fossils in Leg 111 and 113 Sites (Kawahata and Ishizuka, 1989; Kawahata et al., in press).

The THAA data from Leg 116 reveal the following order of amino acid abundance: neutral $>$ acidic $>$ basic $>$ aromatic $>$ sulfur-containing. This is similar to that of Hole 677, Leg 111, Table 3 (Kawahata and Ishizuka, 1989). The relative abundance of straight-chain amino acids is most dominant in the neutral fraction. The second-most dominant fraction is hydroxyl amino acid. Within the hydroxyl fraction, there is a predominance of serine at Sites 718 and 719 as is seen in the marine suspension (Siezen and Mague, 1978). Concentrations of branch-chain amino acids including valine, leucine, and iso-leucine in the three sites is not similar to that found in the marine plankton and

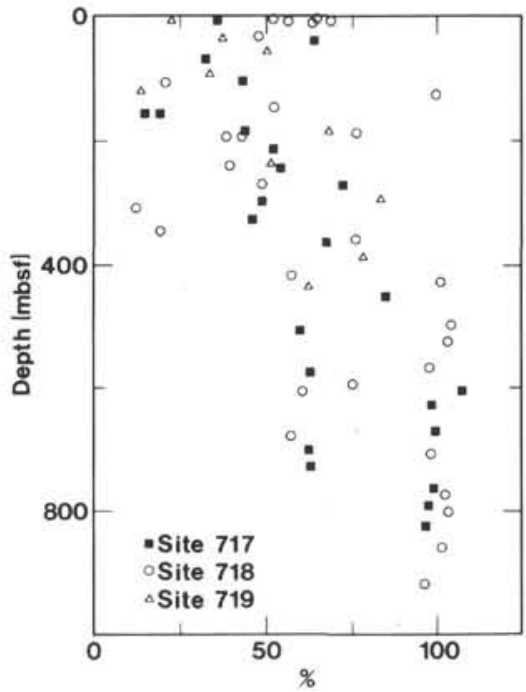

Figure 4. Ratios of dissolved free amino acid to total hydrolyzable amino acid of interstitial water, ODP Leg 116. 
marine and river suspensions (Raymont et al., 1975; Peake et al., 1972; and Siezen and Mague, 1978). In the acidic fraction, glutamic acid is two to three times more concentrated than aspartic acid, consistent with concentrations at Site 677 , but aspartic acid is different from that of marine planktons and oceanic and terrestrial suspensions (Raymont et al., 1975; Siezen and Mague, 1978; and Peake et al., 1972) In the basic fractions, ornithine is the major amino acid and arginine the minor one at the three Leg 116 sites, in spite of predominance of arginine in marine plankton (Raymont et al., 1975). This difference may be the result of decomposition from arginine to ornithine during diagenesis.

Overall, the composition of the THAA at the three Leg 116 Sites differs in the content of marine plankton (Raymont et al., 1975), the nature of oceanic and terrestrial material (Siezen and Mague, 1978; Peake et al., 1972), and in the composition of interstitial water compared to ESOPE core 48 that was recovered from pelagic sediment in the Atlantic (Ishizuka et al., 1988). The differences indicate a more dominant terrestrial influence on the THAA composition of interstitial water in the three Leg 116 sites, similar to that observed at Site 677 from Leg 111.

\section{ACKNOWLEDGMENTS}

The authors express their sincere gratitude and deep appreciation to the late E. T. Degens (Geological-Paleontological Institute, University of Hamburg). Special thanks also for the support of K. Kobayashi (Ocean Research Institute, University of Tokyo). We thank the Japanese ODP committee for providing a travel grant to the first author to participate on Leg 116.

\section{REFERENCES}

Degens, E. T., and Mopper, K., 1976. Factors controlling the distribution and early diagenesis of organic material in marine sediments. In Riley, J. P., and Chester, R. (Eds.), Chemical Oceanography (Vol. 6): New York (Academic Press), 60-114.

Henriches, S. M., and Farrington, J. W., 1979. Amino acids in interstitial waters of marine sediments. Nature, 279:319-322.

J. M., 1987. Early diagenesis of amino acids and organic matter in two coastal marine sediments. Geochim. Cosmochim. Acta, 51:1-15.

Ishizuka, T., Nozaki, Y., and Shimooka, K., 1988. Amino acids in the interstitial waters of ESOPE long cores from two North Atlantic abyssal plains. Geochem. J., 22:1-8.
Kawahata, H., and Ishizuka, T., 1989. Organic properties of sediments and amino acids in interstitial waters from the flank of Costa Rica Rift, Galapagos Spreading Center (ODP Sites 677 and 678). In Becker, K., Sakai, H., et al., Proc. ODP, Sci. Results, 111: College Station, TX (Ocean Drilling Program), 215-225.

Kawahata, H., Ishizuka, T., and Nagao, T., 1989. Amino acids in the interstitial waters from ODP Site 695 in the Weddell Sea, Antarctic Ocean. In Barker, P. F., Kennett, J. P., et al., Proc. ODP, Sci. Results, 113: College Station, TX (Ocean Drilling Program).

Michaelis, W., Mycke, B., Vogt, J., Schuetze, G. and Degens, E. T., 1982. Organic geochemistry of interstitial waters, Sites 474 and 479, Leg 64. In Curray, J. R., and Moore, D. G., et al., Init. Repts. DSDP, 64 (Pt. 2): Washington (U.S. Govt. Printing Office), 933-937.

Mooris, R. J., 1975. The amino acid composition of a deep-water marine sediment from the upwelling region northwest of Africa. Geochim. Cosmochim. Acta, 39:381-388.

Peake, E. P., Baker, B. L., and Hodgsons, G. W., 1972. Hydrogeochemistry of the surface waters of the Mackenzie River drainage basin, Canada. II. The contribution of amino acids, hydrocarbons and chlorine to the Beaufort Sea by the Mackenzie River system. Geochim. Cosmochim. Acta, 36:867-883.

Raymont, J.E.G., Morris, R. J., Ferguson, C. F., and Raymont, J.K.B., 1975. Variation in the amino acid composition of lipid-free residues of marine animals from the northeast Atlantic. J. Exp. Mar. Biol. Ecol., 17:261-267.

Rosenfeld, J. K., 1979. Amino acid diagenesis and adsorption in near-shore anoxic sediments. Limnol. Oceanogr., 24:1014-1021.

Shipboard Scientific Party, 1989a. Site 717: Bengal Fan. In Cochran, J. R., Stow, D.A.V., et al., Proc. ODP, Init. Repts., 116: College Station, TX (Ocean Drilling Program), 45-90.

1989b. Site 718: Bengal Fan. In Cochran, J. R., Stow, D.A.V., et al., Proc. ODP, Init. Repts., 116: College Station, TX (Ocean Drilling Program), 91-154.

1989c. Site 719: Bengal Fan. In Cochran, J. R., Stow, D.A.V., et al., Proc. ODP, Init. Repts., 116: College Station, TX (Ocean Drilling Program), 155-196.

Siezen, R. J., and Mague, T. H., 1978. Amino acids in suspended particulate matter from oceanic and coastal waters of the Pacific. Mar. Chem., 6:215-231.

Whelan, J. K., 1977. Amino acids in a surface sediment core of the Atlantic abyssal plain. Geochim. Cosmochim. Acta, 41:803-810.

Date of initial receipt: 18 April 1989

Date of acceptance: 24 January 1990

Ms 116B-135 